\title{
Tubal patency after Laparoscopic salpingostomy versus Methotrexate therapy in undisturbed tubal pregnancy
}

Waleed M. Tawfik *, Ali A. Bendary and Mohamed A. Elgazar

Department of Obstetrics \& Gynecology, Faculty of Medicine - Benha University. Benha, Egypt.

Corresponding author: Waleed M. Tawfik, Lecturer in Department of Obstetrics \& Gynecology, Faculty of Medicine - Benha University. Benha, Egypt.

Received date: July 07, 2021; Accepted date: July 12, 2021; Published date: August 09, 2021

Citation: Waleed M. Tawfik, Ali A. Bendary and Mohamed A. Elgazar, (2021) Tubal patency after Laparoscopic salpingostomy versus Methotrexate therapy in undisturbed tubal pregnancy J. Obstetrics Gynecology and Reproductive Sciences 5(6) DOI:10.31579/2578-8965/090

Copyright: (C) 2021, Waleed M. Tawfik, This is an open access article distributed under the Creative Commons Attribution License, which permits unrestricted use, distribution, and reproduction in any medium, provided the original work is properly cited.

\begin{abstract}
:
Future fertility after ectopic pregnancy is dependent on several factors, including age, history of infertility, history of previous EP, tubal rupture, and contralateral tubal lesion. Thus, it seems reasonable to assess tubal patency following a treatment of an ectopic pregnancy in those women who are willing to have future pregnancy.

Aimed to: Compare between tubal patency after methotrexate \& laparoscopic salpingostomy.

The study included 72 patients equally divided in number into 2 main groups.

First group: (36cases) Tubal ectopic pregnancy treated by MXT therapy single or multiple doses. Single dose regimen (MTX $1.0 \mathrm{mg} / \mathrm{kg}$ or $50 \mathrm{mg} / \mathrm{m} 2$ i.m or multiple dose regimen (MTX $1.0 \mathrm{mg} / \mathrm{kg}$ i.m days $(0,2,4,6)$.

Second group: - (36 cases) Tubal ectopic pregnancy treated by laparoscopic salpingostomy.

After 3 months, we used laparoscopy with administration of methylene blue (MB) as a marker to detect the tubal patency.

As regard to tubal patency, of 31 cases $(86.1 \%)$ from 36 cases that treated by MTX were patent and 5 cases $(13.9 \%)$ were blocked. On the other side 21 cases $(58.3 \%)$ from 36 cases that treated by laparoscopic salpingostomy were patent and 15 cases $(41.7 \%)$ were blocked).
\end{abstract}

Conclusions: Methotrexate is better than laparoscopic salpingostomy in treating undisturbed tubal pregnancy.

Keywords: laparoscopy; methotrexate; tubal pregnancy

\section{Introduction}

In the western world 4-10\% of pregnancy-related deaths have been observed, from this issue and now it is a growing problem in developing countries also. The annual incidence of ectopic pregnancy has increased over the past 30 years [1].

Although advances in diagnostic methods have allowed for earlier diagnosis, it still remains a life-threatening condition. Approximately, $75 \%$ of deaths in the first trimester and $9 \%$ of all pregnancy-related deaths are due to EP [2].

By the 1920s, laparotomy and ligation of the bleeding vessels with removal of the affected tube had become the standard of care, and it remained so until the late 1970s, when operative laparoscopy and salpingostomy replaced laparotomy and salpingectomy [3]. In the 1980s and 1990s, medical therapy for ectopic pregnancy was implemented; it has now replaced surgical therapy in many cases. Thus, in less than 3 decades, management of ectopic pregnancy has evolved from emergency surgical treatment to conservative medical treatment [4].

Future fertility after ectopic pregnancy is dependent on several factors, including age, history of infertility, history of previous EP, tubal rupture, and contralateral tubal lesion [5]. Thus, it seems reasonable to assess tubal patency following a treatment of an ectopic pregnancy in those women who are willing to have future pregnancy [6].

\section{Aim of the Work}

Study the effect of methotrexate therapy compared with laparoscopic salpingostomy done in the management of EP on subsequent later on tubal patency.

\section{Patients \& Methods:}

The present study is a prospective study between (2019 -2020). It was conducted at Obstetrics \& Gynecology Department Benha University 
hospital after obtaining informed written consent and ethical committee. The study involved 72 cases, thirty six in each group as average number of patients admitted for tubal pregnancy.

\section{Inclusion criteria:}

- Hemodynamically stable

- $\quad$ Unruptured tubal pregnancy.

- $\quad$ Sérum quantitative $\beta-\mathrm{HCG}<5000 \mathrm{IU} / \mathrm{L}$

- $\quad$ Size of ectopic mass $<3.5 \mathrm{~cm}$ and no embryonic cardiac motion.

- $\quad$ Normal liver function test, kidney function \& electrolytes, and complete blood count (CBC)

- $\quad$ Patient compliance for regular follow up (average follow up 35 days)

\section{Exclusion criteria:}

- $\quad$ Clinically unstable

- $\quad$ Severe or persistent abdominal pain or evidence of significant hemoperitoneum on ultrasound scan $(>300 \mathrm{~mL})$ presence of free fluid in pelvis or in abdomen \& pelvis.

- $\quad$ Sérum quantitative $\beta-\mathrm{HCG}$ > $5000 \mathrm{IU} / \mathrm{L}$.

- $\quad$ Ectopic mass $>3.5 \mathrm{~cm}$.

- $\quad$ The presence of cardiac activity in an ectopic pregnancy.

- Coexistent viable intrauterine pregnancy (heterotopic pregnancy).

- Non-compliant patient / patient living far away from the hospital.

- Clinically significant renal, hepatic or hematological impairment.
- Known hypersensitivity to methotrexate.

- Breast feeding.

- Immunodeficiency / concurrent use of corticosteroids.

The study included 72 patients equally divided in number into $\mathbf{2}$ main groups:

First group :-( 36cases) Tubal ectopic pregnancy treated by MXT therapy (20 case) by single dose and (16 case) by multiple doses.

Single dose regimen (MTX $1.0 \mathrm{mg} / \mathrm{kg}$ i.m), multiple dose regimen (MTX $1.0 \mathrm{mg} / \mathrm{kg}$ i.m daily $0,2,4,6)$.

Second group: - (36 cases) Tubal ectopic pregnancy treated by laparoscopic salpingostomy.

Three months later tubal patency testing for all cases by laparoscopy using methylene blue test.

\section{Data collection}

(Missed period less than or equal to 45 days) at 2-4-day intervals, to examine the rate of increase in HCG values. Measure of serum HCG level at the time of the first transvaginal ultrasound examination, was below the discriminatory zone of $1000 \mathrm{IU} / \mathrm{l}$.

Women who diagnosed as having an ectopic pregnancy. The increase in HCG progressed only slowly, with a doubling time exceeding 2.2 days. The doubling time of HCG is a useful diagnostic aid in cases where transvaginal ultrasound has not (yet) given a definite answer regarding the presence of an intra-uterine pregnancy [7].

A tubal pregnancy should be suspected if ultrasonography reveals gestational tissue in the adnexal area without any evidence of an intrauterine pregnancy. If a yolk sac or embryo is seen in the ectopic gestational tissue, the diagnosis of ectopic pregnancy is definitively confirmed [8].

\begin{tabular}{|l|l|}
\hline \multicolumn{1}{|c|}{ Day } & \multicolumn{1}{c|}{ Management } \\
\hline 1 & Serum HCG \\
\hline 1 & Intramuscular Methotrexate $50 \mathrm{mg} / \mathrm{m} 2$ \\
\hline 4 & Serum HCG \\
\hline 7 & $\begin{array}{l}\text { Serum HCG If HCG decrease }>15 \% \text { day 4-7, repeat HCG weekly. 2nd dose of Methotrexate } \\
50 \mathrm{mg} / \mathrm{m} 2 \text { if HCG decrease }<15 \% \text { day } 4-7\end{array}$ \\
\hline 14 & $\begin{array}{l}\text { Serum HCG If HCG decrease }>15 \% \text { day } 7-14, \text { repeat HCG weekly 3rd dose of Methotrexate } \\
50 \mathrm{mg} / \mathrm{m} 2 \text { if HCG decrease }<15 \% \text { day } 7-14\end{array}$ \\
\hline Monitoring & The HCG is followed weekly until the level is <10 IU/L. \\
\hline $\begin{array}{l}\text { Laparoscopy: } \\
\text { If 3 doses have been given and there is a < 15\% HCG decline from day 14 to 21. } \\
\text { If severe abdominal pain or signs suggestive of tubal rupture [9]. }\end{array}$ \\
\hline
\end{tabular}

\section{Laparoscopic procedure:}

1-Under general anesthesia was used in all patients. 2-The patient is placed in a dorso-lithotomy position with the buttocks extended over the end of the table. 3-The thighs should be flexed $\left(120^{\circ}\right)$ to allow good instrument manipulation. Sterilization, foley catheter is placed in the bladder. 5-After placement of a cervical tenaculum, a Robins cannula is inserted into the cervix. Laparoscopic salpingostomy. Tubal ectopic pregnancy once diagnosed, first we check the healthy tube then treat the diseased one if the pregnancy is in the mid-ampullary segment as in solution of vasopressin $(20 \mathrm{U} / 100 \mathrm{~mL}$ the majority of cases, a $5-7 \mathrm{~mL}$ dilute of NS) is used. This is injected with a laparoscopic needle into the mesosalpinx just below the pregnancy and over the anti-mesenteric surface of the segment containing the gestation. Using a laser, microelectrode, scissors, or harmonic scalpel a linear incision is made over the pregnancy approximately $1-2 \mathrm{~cm}$ in length. As one makes this incision the contents of the pregnancy usually begin to extrude. This can be completed by hydro dissection or using gentle traction with laparoscopic forceps. In some cases, more forceful irrigation in the salpingostomy incision may be required to dislodge the pregnancy from its implantation site. Occasionally, coagulation is used to secure hemostasis and is best accomplished with bipolar micro-forceps. Copious irrigation is used to dislodge trophoblastic tissue and remove blood from the peritoneal cavity. The tubal opening is left to heal by secondary intention, unless the defect is wide, and the edges do not come together spontaneously. For such cases, the edges may be approximated with a single 4-0 absorbable suture [10] 


\section{Outcome:}

3 to 6 months tubal patency for all cases was evaluated by laparoscopy using methylene blue (MB) test at the time of surgery.

\section{Statistical Analysis}

- $\quad$ The collected data were computerized and statistically analyzed using SPSS program (Statistical Package for Social Science) version 18.0.

\begin{tabular}{|c|c|c|c|c|c|c|}
\hline Variable & \multicolumn{2}{|c|}{$\begin{array}{c}\text { Group I } \\
\text { Mtx } \\
(n=36) \\
\end{array}$} & \multicolumn{2}{|c|}{$\begin{array}{c}\text { Group II } \\
\text { Lap } \\
(\mathbf{n}=36) \\
\end{array}$} & $\mathbf{T}$ & $\mathbf{P}$ \\
\hline $\begin{array}{l}\text { Age: (year) } \\
\text { Mean } \pm S D \text {. } \\
\text { Range }\end{array}$ & \multicolumn{2}{|c|}{$\begin{array}{c}25.72 \pm 4.66 \\
18-37\end{array}$} & \multicolumn{2}{|c|}{$\begin{array}{c}25.39 \pm 4.46 \\
19-36 \\
\end{array}$} & 0.31 & $\begin{array}{c}0.76 \\
\text { NS }\end{array}$ \\
\hline $\begin{array}{l}\text { BMI: }\left(\mathbf{K g} / \mathbf{m}^{\mathbf{2}}\right) \\
\text { Mean } \pm S D . \\
\text { Range } \\
\end{array}$ & \multicolumn{2}{|c|}{$\begin{array}{c}30.47 \pm 4.34 \\
22.59-39.16 \\
\end{array}$} & \multicolumn{2}{|c|}{$\begin{array}{l}29.13 \pm 3.43 \\
22.6-38.28\end{array}$} & 1.46 & $\begin{array}{l}0.15 \\
\text { NS }\end{array}$ \\
\hline Variable & No & $\%$ & No & $\%$ & $\chi^{2}$ & $\mathbf{P}$ \\
\hline $\begin{array}{l}\text { Parity: } \\
\text { PG } \\
1-3 \\
4-6\end{array}$ & $\begin{array}{c}7 \\
27 \\
2\end{array}$ & $\begin{array}{c}19.4 \\
75 \\
5.6\end{array}$ & $\begin{array}{c}10 \\
24 \\
2\end{array}$ & $\begin{array}{c}27.8 \\
66.6 \\
5.6\end{array}$ & 0.71 & $\begin{array}{c}0.70 \\
\text { NS }\end{array}$ \\
\hline
\end{tabular}

SD: Stander deviation t: Independent t test $\chi 2$ : Chi square test NS: Nonsignificant $(\mathrm{P}>0.05)$

Table (1) shows the demographic data of the two studied groups. There was no statistically significant difference between the two studied groups in age, parity or BMI.

Table (2): Symptoms between the two studied groups:

\begin{tabular}{|c|c|c|c|c|c|c|}
\hline \multirow[t]{2}{*}{ Variable } & \multicolumn{2}{|c|}{$\begin{array}{c}\text { Group I } \\
\text { Mtx } \\
(n=36)\end{array}$} & \multicolumn{2}{|c|}{$\begin{array}{c}\text { Group II } \\
\text { Lap } \\
(\mathbf{n}=36) \\
\end{array}$} & \multirow[t]{2}{*}{$\chi^{2}$} & \multirow[t]{2}{*}{$\mathbf{P}$} \\
\hline & No & $\%$ & No & $\%$ & & \\
\hline $\begin{array}{l}\text { Abdominal pain: } \\
Y e s \\
\mathrm{No}\end{array}$ & $\begin{array}{c}33 \\
3\end{array}$ & $\begin{array}{c}91.7 \\
8.3\end{array}$ & $\begin{array}{c}35 \\
1\end{array}$ & $\begin{array}{c}97.1 \\
2.8\end{array}$ & 1.06 & $\begin{array}{c}0.30 \\
\text { NS }\end{array}$ \\
\hline $\begin{array}{l}\text { Vaginal bleeding: } \\
\text { No } \\
\text { Yes }\end{array}$ & $\begin{array}{c}36 \\
0\end{array}$ & $\begin{array}{c}100 \\
0\end{array}$ & $\begin{array}{c}36 \\
0\end{array}$ & $\begin{array}{c}100 \\
0\end{array}$ & 0 & $\begin{array}{c}1 \\
\mathrm{NS}\end{array}$ \\
\hline
\end{tabular}

$\chi 2$ : Chi square test NS: Nonsignificant $(\mathrm{P}>0.05)$

Table (2) shows the basic symptoms between the two studied groups. There was no statistically significant difference between the two studied groups in frequency of abdominal pain or vaginal bleeding.

Table (3): Size \& site of lesions between the two studied groups:

\begin{tabular}{|c|c|c|c|c|c|c|}
\hline Variable & \multicolumn{2}{|c|}{$\begin{array}{c}\text { Group I } \\
\text { Mtx } \\
(n=36)\end{array}$} & \multicolumn{2}{|c|}{$\begin{array}{c}\text { Group II } \\
\text { Lap } \\
(n=36)\end{array}$} & MW & $\mathbf{P}$ \\
\hline $\begin{array}{l}\text { Size: }\left(\mathbf{m m}^{\mathbf{2}}\right) \\
\text { Mean } \pm S D . \\
\text { Median } \\
\text { Range }\end{array}$ & \multicolumn{2}{|c|}{$\begin{array}{c}600.61 \pm 216.32 \\
574 \\
345-1122 \\
\end{array}$} & \multicolumn{2}{|c|}{$\begin{array}{c}553.19 \pm 174.63 \\
525 \\
320-1088\end{array}$} & 0.98 & $\begin{array}{c}0.33 \\
\mathrm{NS}\end{array}$ \\
\hline Variable & No & $\%$ & No & $\%$ & $\chi^{2}$ & $\mathbf{P}$ \\
\hline $\begin{array}{l}\text { Site: } \\
R t \\
L t\end{array}$ & $\begin{array}{l}26 \\
10\end{array}$ & $\begin{array}{c}72.2 \\
27.8\end{array}$ & $\begin{array}{c}27 \\
9\end{array}$ & $\begin{array}{l}75 \\
25\end{array}$ & 0.08 & $\begin{array}{c}0.79 \\
\text { NS }\end{array}$ \\
\hline
\end{tabular}

SD: Stander deviation MW: Mann Whitney test $\chi 2$ : Chi square test NS:Non significant $(\mathrm{P}>0.05)$

Table (3) shows the size and site of lesions. There were no statistically significant difference between the two studied groups as regard size or site of lesions. 
Table (4): HCG between the two studied groups:

\begin{tabular}{|l|c|c|c|c|}
\hline \multicolumn{1}{|c|}{ Variable } & $\begin{array}{c}\text { Group I } \\
\text { Mtx } \\
(\boldsymbol{n = 3 6 )}\end{array}$ & $\begin{array}{c}\text { Group II } \\
\text { Lap } \\
(\mathbf{n = 3 6})\end{array}$ & MW & P \\
\hline HCG: $(\mathbf{u} / \mathbf{l})$ & $3012.2 \pm 1228.75$ & $3293.1 \pm 1260.62$ & & \\
Mean \pm SD. & 1022 & 1060.5 & 0.31 & 0.76 \\
Median & $99.4-4946$ & $124.7-4856$ & NS \\
Range &
\end{tabular}

SD: Stander deviation MW: Mann Whitney test NS: Nonsignificant $(\mathrm{P}>0.05)$

Table (4) shows the HCG level of the two studied groups. There was no statistically significant difference between the two studied groups as regard HCG level.

Table (5): Tubal patency between the two studied groups:

\begin{tabular}{|c|c|c|c|c|c|c|}
\hline \multirow[t]{2}{*}{ Variable } & \multicolumn{2}{|c|}{$\begin{array}{c}\text { Group I } \\
\text { Mtx } \\
(n=36)\end{array}$} & \multicolumn{2}{|c|}{$\begin{array}{c}\text { Group II } \\
\text { Lap } \\
(n=36)\end{array}$} & \multirow[t]{2}{*}{$\chi^{2}$} & \multirow[t]{2}{*}{$\mathbf{P}$} \\
\hline & No & $\%$ & No & $\%$ & & \\
\hline $\begin{array}{l}\text { Tube: } \\
\text { Patent } \\
\text { Not patent }\end{array}$ & $\begin{array}{c}31 \\
5\end{array}$ & $\begin{array}{l}86.1 \\
13.9\end{array}$ & $\begin{array}{l}21 \\
15\end{array}$ & $\begin{array}{l}58.3 \\
41.7\end{array}$ & 6.92 & $0.009 * *$ \\
\hline
\end{tabular}

$\chi 2$ : Chi square test NS: Nonsignificant $(\mathrm{P}>0.05)$

Table (5) shows tubal patency after ttt. There was highly statistically significant increase in frequency of non-patent tube in laparoscopic salpingostomy group compared to Methotrexate group.

\section{Discussion}

The annual incidence of EP has increased over the past 30 years. Four$10 \%$ of pregnancy-related deaths have been observed due to ectopic pregnancy [10].

Future fertility after ectopic pregnancy is dependent on several factors, including age, history of infertility, history of previous EP, tubal rupture, and contralateral tubal lesion [11]. Thus, it seems reasonable to assess tubal patency following a treatment of an EP in those women who are willing to have future pregnancy.

In present study we detect tubal patency using laparoscopy guided by methylene blue after treatment of tubal pregnancy by methotrexate or laparoscopic salpingostomy.

This study was in Obstetrics \& Gynecology Department Benha University hospital. Thirty-six cases treated by administration of MTX \& thirty-six cases treated by laparoscopic salpingostomy.

\section{The end results of our study}

As regard to tubal patency of 31 cases $(86.1 \%)$ from 36 cases that treated by MTX were patent and 5 cases $(13.9 \%)$ were blocked. On the other side 21 cases $(58.3 \%)$ from 36 cases that treated by laparoscopic salpingostomy were patent and 15 cases $(41.7 \%)$ were blocked.

Comparing Laparoscopic salpingostomy alone versus laparoscopic salpingostomy with single-dose systemic MTX. They reported that salpingostomy alone was significantly less successful than when combined with a prophylactic single dose of systemic $1 \mathrm{mg} / \mathrm{kg}$ i.m. MTX (RR 0.89 , 95\% CI $0.82-0.98$ ), given within $24 \mathrm{~h}$ post-operatively to prevent persistent trophoblast [12]. This agrees with our study.

Comparing Systemic MTX in a fixed multiple dose regimen with laparoscopic salpingostomy. They reported that no significant differences were found in tubal patency between the two groups [13].This disagrees with our study due to the difference of gravidity and parity.
Comparing systemic MTX in a single-dose regimen with laparoscopic salpingostomy. They reported that no significant differences were found in tubal patency between the two groups [14].

This disagrees with our study because they used only single dose MTX regimen, but we used single or multiple doses.

Comparing systemic MTX in a single-dose regimen with laparoscopic salpingostomy. They reported that tubal patency in patients treated with methotrexate was $84 \%$ and in salpingostomy patients it was $83 \%$. The success rate for tubal patency with methotrexate was the same as that for surgery [15].

This disagrees with our study due to their higher levels of hCG- $\beta$ that reduce the chance of tube patency.

Comparing medical versus surgical treatment. They reported that systemic treatment with variable dose methotrexate regimen is as effective as laparoscopic salpingostomy (82 - 95\% MTX Vs $80-92 \%$ Salpingostomy) [16]. This agrees with our study.

\section{Conclusions}

Methotrexate is better than laparoscopic salpingostomy in treating undisturbed tubal pregnancy.

\section{References:}

1. Barnhart KT, Sammel MD, Rinaudo PF, et al. (2014) Symptomatic patients with an early viable intrauterine pregnancy: HCG curves redefined. Obstet Gynecol. 104:50-55.

2. Bouyer J, Coste J, Shojaei T. (2003) Risk factors for ectopic pregnancy: a comprehensive analysis based on a large casecontrol, population-based study in France. Am J Epidemiol. 157:185-194

3. Ezzati M, Djahanbakhch O, Arian S, Carr BR. (2014) Tubal transport of gametes and embryos: a review of physiology and pathophysiology. J Assist Reprod Genet.

4. Goyaux N, Leke R, Keita N, Thonneau P. (2003) Ectopic pregnancy in African developing countries. Acta Obstet Gynecol Scand. 82(4):305-12. 
5. Horne AW, Shaw JL, Murdoch A, et al. (2019) Placental growth factor: a promising diagnostic biomarker for tubal ectopic pregnancy. J Clin Endocrinol Metab. 96: E104-E108.

6. Kirk E, Condous G, Van Calster B, Haider Z, Van Huffel S, Timmerman D, et al. (2007) A validation of the most commonly used protocol to predict the success of single-dose methotrexate in the treatment of ectopic pregnancy. Human Reproduction. 22(3):858-63.

7. Lipscomb GH. (2012) Medical Management of Ectopic Pregnancy. Clinical Obstetrics \& Gynecology. 55(2):424-32.

8. Royal College of Obstetricians and Gynecologists. Ectopic pregnancy and miscarriage: Diagnosis and initial management in early pregnancy of ectopic pregnancy and miscarriage. NICE Clinical Guidelines. 2012:1287.

9. Shaw JL, Oliver E, Lee KF. (2019) Cotinine exposure increases fallopian tube PROKR1 expression via nicotinic AChRalpha-7: a potential mechanism explaining the link between smoking and tubal ectopic pregnancy. Am J Pathol. 177:2509-2515 (a)

10. Szkodziak P, Wozniak S, Czuczwar P, Paszkowski T, Milart P, Wozniakowska E, et al. (2014) Usefulness of three-dimensional transvaginal ultrasonography and hysterosalpingography in diagnosing uterine anomalies. Ginekol Pol. 85(5):354-9.
11. Talbot P, Riveles K. (2005) Smoking and reproduction: the oviduct as a target of cigarette smoke. Reprod Biol Endocrinol. 3:52.

12. Wedderburn CJ, Warner P, Graham B, Duncan WC, Critchley HO, Horne AW. (2010) Economic evaluation of diagnosing and excluding ectopic pregnancy. Hum Reprod. 25:328-333.

13. Weigert M, Gruber D, Pernicka E, Bauer P, Feichtinger W. (2009) Previous tubal ectopic pregnancy raises the incidence of repeated ectopic pregnancies in in vitro fertilization-embryo transfer patients. J Assist Reprod Genet. 26:13-17.

14. Williams S, Peipert J, Buckel C, Zhao Q, Madden T, Secura G.(2 014) Contraception and the risk of ectopic pregnancy. Contraception. 90(3):326

15. Xu Z, Yan L, Liu W, Xu X, Li M, Ding L, et al. (2015) Effect of treatment of a previous ectopic pregnancy on in vitro fertilization-intracytoplasmic sperm injection outcomes: a retrospective cohort study. Fertil Steril. 104 (6):1446-51. e1-3.

16. Morin L, Van den Hof MC. (2005) Diagnostic Imaging Committee, Society of Obstetricians and Gynecologists of Canada. Ultrasound evaluation of first trimester pregnancy complications. J Obstet Gynaecol Can. 27:581-591.

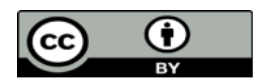

This work is licensed under Creative Commons Attribution 4.0 License

\section{To Submit Your Article Click Here: Submit Manuscript}

DOI: $10.31579 / 2578-8965 / 072$
Ready to submit your research? Choose Auctores and benefit from:

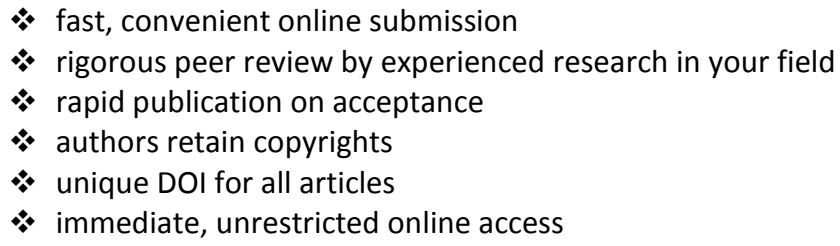

At Auctores, research is always in progress.

Learn more https://auctoresonline.org/journals/obstetrics-gynecologyand-reproductive-sciences 